九州大学学術情報リポジトリ

Kyushu University Institutional Repository

\title{
The Gonimoblast Development In Ceramiaceous Algae Of Japan I
}

Segawa, Sokichi

Fisheries Laboratry, Department of Agriculture, Kyusyu University

https://doi.org/10.5109/22618

出版情報：九州大学大学院農学研究院紀要. 9 (2)，pp.143-147，1949-05. Kyushu University バージョン：

権利関係 : 


\section{THE GONIMOBI.AST DEVELOPMENT IN CERAMPACEOUS ALGAE OF JAPAN. I*}

\section{SOKICHI SEgAWA}

The developmental studies of the reproductive organs in the algae of the family Ceramicaceae were carried out extensively by Kylin ${ }^{3}$, who used the materials taken mostly from the Atlantic ocean. The investigations of Japanese members of this group are of interest.

\section{Callithamnion callophyllidicola Yamada}

As to the gonimoblast development of this alga, the writer previously made some studies published in Japanese. ${ }^{3}$. The material was collected by the writer from Susaki, Izu Province. The identification of the material used was ascertained by comparison with that of Enoshima, the type locality of 'this species.

The carpogonial branch arises on an intercalary vegetative cell in the upper normal branch of this weed. By this central cell two pericentral cells are laterally produced on both sides of it; later each cell in question becomes an auxiliary mother cell; one of two lateral cells of the central cell becomes a supporting cell bearing a carpogonial branch composed of four cells. Thus, the fertile central cell of the upper normal branch has two lateral cells and a four-celled carpogonial branch supported by one of the lateral cells.

\footnotetext{
* Contribution from the Fisheries Laboratory, Faculty of Agriculture, Kyūshu University, Fukuoka, \& the Mitsui Institute of Marine Biology, Susaki near Shimoda. Izu.
} 
After fertilization each auxiliary mother cell cuts off an auxiliary cell upwards. Each auxiliary cell issues a process towards the fertilized carpogonium. At the same time the fertilized carpogonium becomes inflated horizontally and cuts off a somewhat large cell by an oblique vertical wall. At the advanced stage the latter cell produces one small cell, and the fertilized carpogonium itself also cuts off a small cell. These cells newly produced from the carpogionium are the connecting cells. Therefore it is concluded that the carpogonium issues a connecting cell and a two-celled connecting filament. The auxiliary cell produced from the supporting cell fuses with a connecting cell mentioned above.

After fusion each auxiliary cell produces an initial cell of gonimoblast.

\section{Antithamnion Plumula (Ellis) Thuret}

The gonimoblast development of this species has been studied by Phillips $(1897)^{3 !}$ and more fully by Kylin (1923): in European materials. The material used by the present writer was collected from Onomichi, Bingo Province.

The carpogonial branch arises on the undermost cell of the pinnula of a few cells near the apex. The supporting cell corresponds to a pericentral cell of the central axis. The central cell bearing the pinula and the supporting cell do not differ much from other vegetative cells. The carpogonial branch is four-celled and stands upwards in a curve on one side of the supporting cell:

After fertilization an auxiliary cell is cut off upwards from the supporting cell, and the auxiliary cell is situated near the fertilized carpogonium. The carpogonium cuts off a small cell upwards by a horizontal wall and then another small cell laterally by an oblique vertical wall. The former lies near the base of the trichogyne, and seems to correspond with "a small mass of granular matter" described by Phillips. The latter small cell fuses with the auxiliary cell.

The gonimoblast initial is produced by the auxiliary cell upwards. The gonimoblast consists of 2 or 3 gonimolobes pro duced from the initial. The gonimoblast is surrounded by in volucres produced from central cells near to it. 


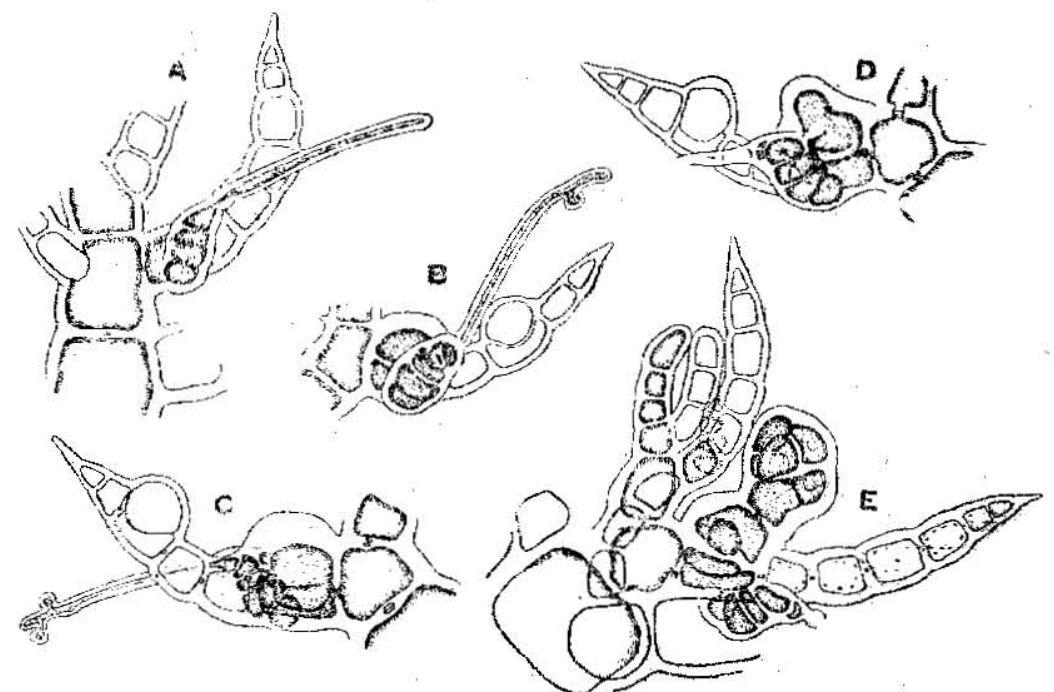

Fig. 1. Antithamnion Plumula.

a. procarp.

b-d. procarp after fertilization.

e. development of gonimoblast.

Spermothamnion Tamamiru Segawa

The material of this study was collected from Susaki, Izu Province. The species is rather common in this locality and found on Codium mamillare as an endophytic alga.

The fertile part of the female individual is on the top of the erect filament or its branchlet, and consists of three differentiated cells of small size. The middle central cell of three becomes fertile, and cuts off three pericentral cells, the second and third developing one on either side of the first. Then the second pericentral cell cuts off a small cell, which is sterile. After this the former becomes the supporting cell of the four-celled carpogonial branch. The carpogonial branch grows exactiy opposite to the first pericentral cell.

After fertilization the second and third cells become the auxiliary mother cell, and each cuts off an auxiliary cell upwards. On the other hand the fertilized carpogonium cuts off two connecting cells of small size on both sides of it. Then these cells fuse each other with two auxiliary cells mentioned above. 
Each auxiliary cell produces an initial cell of gonimoblast. From the outermost cells of the gonimoblast filaments the carpospores are produced. There are no involucres at all around the gonimoblast.
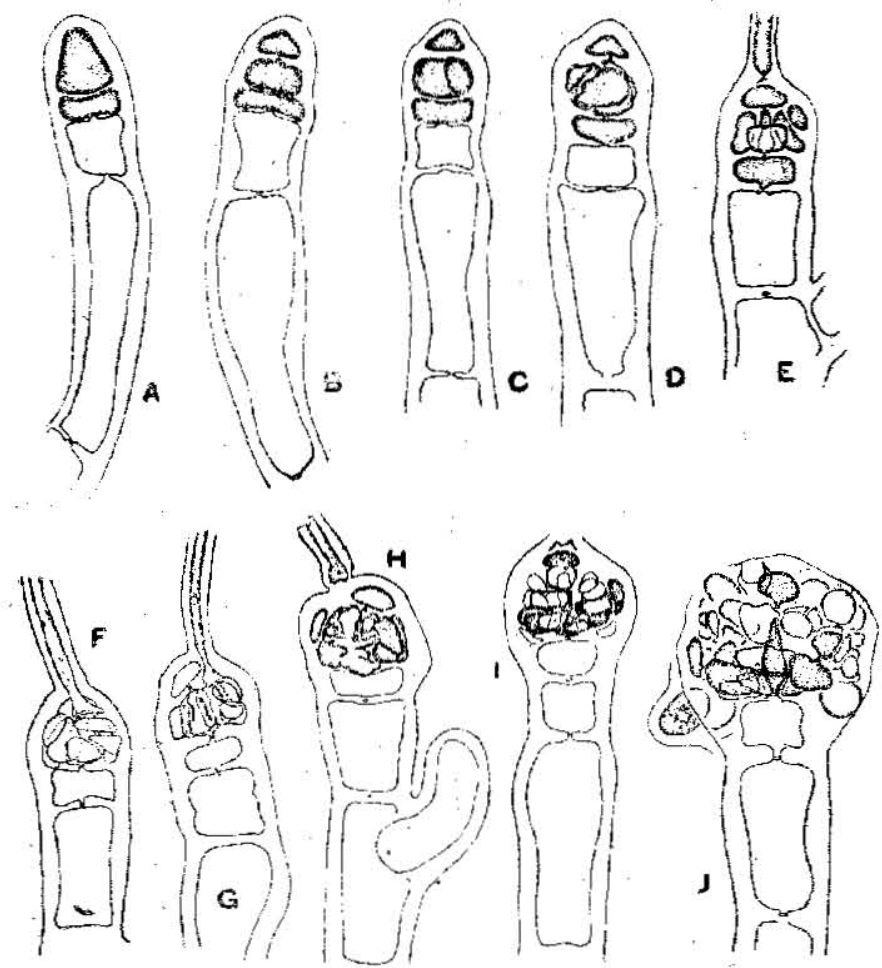

Fig. 2. Spermothamnion Tamamiru. a-g. development of procarp. h. procarp after fertilization.

i-j. development of gonimoblast.

Here the writer wishes to express his hearty thanks to Prof. Dr. Y. Yamada for his kind direction. Thanks are also due to Prof. Dr K. Uchida and Prof. Dr. I. Amemiya for their kind help. 


\section{Literature. Cited}

1) Kylin, H. (1923), Studien ueber die Entwicklungsgeschichte der Florideet, K. Sv. Vet. Akad. Handi., Bd. 63.

Kylin, H. (1930), Ueber die Entwicklungsgeschichte der Florideen, Lunds Univ. Ars., N.F. Ayd. 2, Bd. 26.

2) Segawa, S. (1942), Cystocarp of Callithamnion callophyllidicola, Igaku to Seibutsugaku, vol. 2, no. 4, p. 206-209 (in Japanese)

3) Phillips, R. W. (1897), The development of the cystocarp in Rhodymeniales Ann Bot., vol. 11 , no. 43, p. $347-368$. 